\title{
Analisis Laju Korosi Elektrode Bahan Cu - Zn Dengan Metode Sacrificial Anode Pada Sistem Energi Listrik Alternatif Berbasis Air Laut
}

\author{
Latifah Kamalia $^{(1)^{*}}$, Gurum Ahmad Pauzi ${ }^{(1)}$, dan Sri Wahyu Suciyati ${ }^{(1)}$ \\ (1) Jurusan Fisika FMIPA Universitas Lampung \\ Jl.Prof. Dr. Soemantri Brojonegoro No.1 Gedung Meneng Bandar Lampung 35145 \\ *E-mail:latifahkamalia@gmail.com
}

Diterima (23 Mei 2018), direvisi (14 Juni 2018)

\begin{abstract}
In this study, the addition of aluminum (Al) and magnesium (Mg) at the zinc ( $\mathrm{Zn}$ ) electrode as the sacrifice anode in an alternative sea-based electrical energy system was carried out. The sacrifice anode method is used as a way to prevent the corrosion of Zn electrodes. There are 3 types of electrode treatments, namely $\mathrm{Cu}-\mathrm{Zn}, \mathrm{Cu}-\mathrm{ZnAl}$, and $\mathrm{Cu}-\mathrm{ZnMg}$. The tool is designed to have 20 cells arranged in series and given a load of 3 Watt LED lights. Tool testing is carried out for 72 hours with electrolyte replacement every 24 hours. The measurement results showed that the Cu-ZnMg electrode produced the highest power output compared to the $\mathrm{Cu}-\mathrm{Zn}$ and $\mathrm{Cu}-\mathrm{ZnAl}$ electrodes. The maximum value of power from the $\mathrm{Cu}-\mathrm{ZnMg}$ electrode is $125.71 \mathrm{~mW}$ while the electrodes of $\mathrm{Cu}-\mathrm{Zn}$ and $\mathrm{Cu}$-ZnAl have maximum power values of $49.49 \mathrm{~mW}$ and $52.48 \mathrm{~mW}$ respectively. The value of the intensity of the light generated from the instrument shows that the greater the power released, the higher the intensity of light. The lowest corrosion rate was generated by the $\mathrm{Cu}$-ZnMg electrode of $0.079 \mathrm{~mm} /$ year after 72 hours of testing. This shows that the addition of sacrificial anode metal with a higher potential electrode value can produce higher and longer electrical energy and a lower corrosion rate.
\end{abstract}

Keywords: sacrifice anode, magnesium, aluminium

Abstrak. Pada penelitian ini, telah dilakukan penambahan logam aluminium (Al) dan magnesium (Mg) pada elektrode zink (Zn) sebagai anode korban pada sistem energi listrik alternatif berbasis air laut. Metode anode korban digunakan sebagai salah satu cara dalam mencegah terjadinya korosi elektrode $\mathrm{Zn}$. Terdapat 3 macam perlakuan elektrode, yaitu $\mathrm{Cu}-\mathrm{Zn}, \mathrm{Cu}-\mathrm{ZnAl}$, dan $\mathrm{Cu}-\mathrm{ZnMg}$. Alat didesain memiliki 20 sel yang tersusun secara seri dan diberi beban lampu LED berukuran 3 Watt. Pengujian alat dilakukan selama 72 jam dengan penggantian elektrolit setiap 24 jam. Hasil pengukuran menunjukkan bahwa elektrode $\mathrm{Cu}-\mathrm{ZnMg}$ menghasilkan keluaran daya yang paling tinggi dibandingkan elektrode $\mathrm{Cu}-\mathrm{Zn}$ dan $\mathrm{Cu}-\mathrm{ZnAl}$. Nilai maksimum daya dari elektrode $\mathrm{Cu}-\mathrm{ZnMg}$ sebesar $125,71 \mathrm{~mW}$ sedangkan elektrode $\mathrm{Cu}-\mathrm{Zn}$ dan $\mathrm{Cu}-\mathrm{ZnAl}$ memiliki nilai maksimum daya masing-masing sebesar $49,49 \mathrm{~mW}$ dan 52,48 $\mathrm{mW}$. Nilai intensitas cahaya yang dihasilkan dari alat menunjukkan bahwa semakin besar daya yang dikeluarkan, maka intensitas cahaya semakin tinggi. Laju korosi terendah dihasilkan oleh elektrode $\mathrm{Cu}-\mathrm{ZnMg}$ sebesar $0,079 \mathrm{~mm} / \mathrm{tahun}$ setelah 72 jam pengujian. Hal ini menunjukkan bahwa penambahan logam anode korban dengan nilai potensial elektrode yang lebih tinggi dapat menghasilkan energi listrik yang lebih tinggi dan lama serta laju korosi logam zink yang lebih rendah.

Kata Kunci: anode korban, magnesium, aluminium

\section{PENDAHULUAN}

Laut merupakan salah satu sumber energi alternatif yang dapat diperbaharui dan sangat berlimpah. Indonesia sebagai negara maritim berpotensi dalam mengembangkan energi alternatif berbasis air laut. Air laut dapat dijadikan sebagai bahan baku sel bahan bakar dan baterai, sehingga energi air laut telah banyak 
dimanfaatkan dalam berbagai penelitian [1] Kandungan air laut berupa 96,5\% air murni dan 3,5\% material lainnya. Air laut merupakan elektrolit asam kuat yang mengandung senyawa natrium klorida sebanyak 2,9\% [2]. Adanya partikel bebas pada air laut dapat menghasilkan energi listrik yang murah dan ramah lingkungan [3]. Energi listrik air laut dapat dihasilkan melalui reaksi reduksi-oksidasi (redoks) dalam sel elektrokimia. Untuk menghasilkan energi listrik, jenis sel elektrokimia yang digunakan adalah sel volta. Pada sel volta, suatu elektrolit air laut diberikan dua buah logam sebagai elektrode yang terhubung satu sama lain dan memiliki beda potensial akan menghasilkan energi listrik [4].

Penelitian tentang energi listrik berbasis elektrolit air laut yang telah dilakukan menunjukkan bahwa semakin banyak volume elektrolit dalam sebuah sel elektrokimia, maka energi listrik yang dihasilkan semakin besar [5]. Penelitian lainnya juga menunjukkan bahwa elektrode pasangan tembaga-zink menghasilkan keluaran arus dan tegangan yang lebih tinggi dibandingkan elektrode pasangan tembaga-aluminium dan tembaga-galvalum [6-8]. Pada susunan sel elektrokimia, dapat diketahui bahwa sel elektrode yang tersusun secara seri menghasilkan keluaran tegangan yang semakin tinggi sebanding dengan semakin banyaknya sel sedangkan sel yang tersusun secara paralel menghasilkan keluaran tegangan yang stabil [9]. Selain dapat menghasilkan listrik, kandungan ion klorida pada elektrolit air laut mempunyai sifat korosif terhadap logam.

Korosi merupakan salah satu masalah utama yang mempengaruhi menurunnya keluaran daya listrik sel air laut. Korosi dapat menyebabkan turunnya kualitas dan kekuatan dari suatu bahan. Korosi logam tidak dapat dihindari, tetapi dapat dikurangi tingkat laju korosinya. Aspek-aspek dalam pencegahan korosi, yaitu seleksi material, proteksi katodik dan anodik, pelapisan, dan perubahan media dan inhibitor. Pencegahan laju korosi elektrode pada aspek perubahan media dan inhibitor dilakukan dengan pemfilteran elektrolit dan penambahan natrium bikarbonat pada elektrolit, sehingga dapat menekan laju korosi 9 kali lebih kecil. Akan tetapi, masih terdapat lapisan hitam pada elektrode tembaga [10-11]. Untuk itu, diperlukan aspek lain dalam pencegahan korosi.

Metode sacrificial anode (anode korban) merupakan salah satu cara pencegahan korosi dengan menghubungkan logam yang akan dilindungi dari korosi dengan suatu logam lain yang memiliki potensial standar reduksi lebih kecil daripada logam yang akan dilindungi [12]. Perlindungan dengan anode korban mempunyai kelebihan diantaranya lebih sederhana, stabil, dan biaya perawatan yang lebih rendah [2]. Secara umum, jenis logam yang digunakan sebagai anode korban adalah zink, aluminium, dan magnesium. [13] melakukan penelitian dengan metode anode korban dalam lingkungan aqueous. Berdasarkan pengukuran kehilangan massa, anode korban aluminium mampu menurunkan laju korosi baja sampai $82 \%$. Penelitian tentang anode korban juga dilakukan oleh [14] menghasilkan laju korosi lambung kapal berbahan logam baja dapat ditekan dengan kandungan tertinggi aluminium pada logam anode korban sebesar $97,165 \%$.

Berdasarkan hasil penelitian yang telah dipaparkan, telah dilakukan penelitian tentang analisis laju korosi bahan elektrode logam tembaga dan zink pada sistem energi listrik alternatif berbasis air laut. Penelitian dilakukan dengan menghubungkan logam yang memiliki nilai potensial standar reduksi elektrode yang lebih kecil dari elektrode sebagai anode korban. Logam yang digunakan sebagai anode korban adalah logam aluminium dan magnesium. Logam anode korban dihubungkan ke elektrode dengan cara ditempelkan pada logam zink. Metode proteksi katodik ini 
dapat mencegah laju korosi dan menghasilkan karakteristik elektrik yang lebih baik.

\section{METODE PENELITIAN}

Alat yang digunakan dalam penelitian ini antara lain: mesin gerinda dan gunting, gelas ukur, tang, lightmeter merk Lutron tipe LX-103, multimeter digital tipe DT830D, timbangan digital tipe TL-series, filter air, sel elektrolit berbahan kaca sebanyak 20 sel. Bahan yang digunakan dalam penelitian ini antara lain: air laut berfungsi sebagai elektrolit, logam tembaga dan zink berukuran $4 \times 7 \mathrm{~cm}$ berfungsi sebagai elektrode, logam aluminium dan magnesium berukuran $5 \mathrm{~cm}^{2}$ berfungsi sebagai anode korban, lampu LED 3 watt 12 volt DC, kabel penghubung, aquades dan alkohol $70 \%$ berfungsi sebagai bahan pembersih elektrode.

Penelitian ini menggunakan elektrolit air laut yang telah difilter dan diisikan sebanyak $200 \mathrm{ml}$ ke dalam setiap sel. Sebelum pengujian alat, elektrode tembaga dan zink dibersihkan dengan alkohol $70 \%$ dan aquades. Pada setiap sel terdapat satu pasang elektrode, yaitu logam tembaga sebagai katode dan logam aluminium sebagai anode. Logam anode korban berupa logam aluminium dan magnesium dipasangkan pada elektrode zink. Pada penelitian ini, terdapat 3 perlakuan elektrode, yaitu elektrode tanpa anode korban $(\mathrm{Cu}-\mathrm{Zn})$, elektrode dengan anode korban aluminium ( $\mathrm{Cu}-\mathrm{ZnAl})$, dan elektrode dengan anode korban magnesium $(\mathrm{Cu}-\mathrm{ZnMg})$. Alat penelitian tersusun atas 20 sel elektrolit, 20 pasang elektrode dan lampu LED yang terhubung secara seri (Gambar 1). Pengujian alat dilakukan selama 72 jam dengan jeda pengambilan data tegangan, arus, dan intensitas cahaya setiap 1 jam. Pengukuran tegangan dan arus dengan beban digunakan untuk analisis keluaran daya. Penggantian elektrolit dilakukan setiap 24 jam selama 72 jam pengujian. Pengukuran massa elektrode dilakukan sebanyak 2 kali, yaitu sebelum diuji dan setelah diuji selama 72 jam. Perubahan massa elektrode selama pengujian berfungsi sebagai data dalam menganalisis laju korosi menggunakan Persamaan 1.

$C=\frac{K \times M}{A \times t \times d}$

dengan $\mathrm{C}=$ Laju Korosi (mm/tahun), $\mathrm{K}=$ Konstanta Satuan mm/tahun $\left(8,76 \times 10^{4}\right)$, $\mathrm{M}=$ Kehilangan Massa (gr), $\mathrm{A}=$ Luas permukaan $\left(\mathrm{cm}^{2}\right), \mathrm{t}=$ Waktu (jam), $\mathrm{d}=$ Densitas $\left(\mathrm{gr} / \mathrm{cm}^{3}\right)$

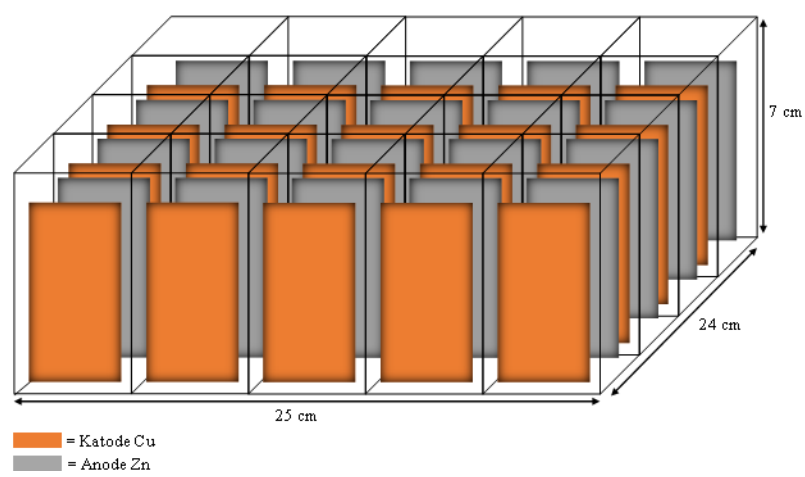

(a)

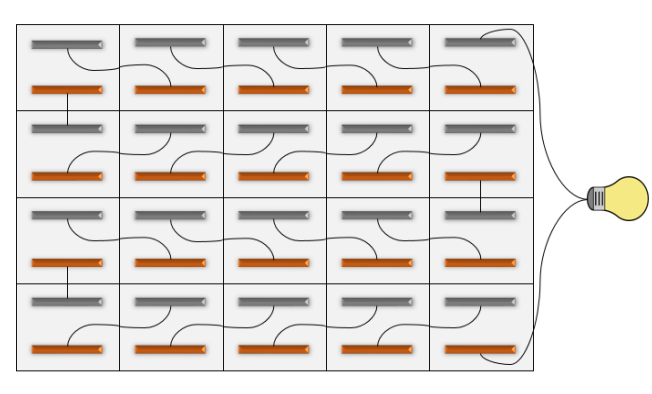

(b)

Gambar 1. (a) Desain sel elektrolit dan (b) Skema susunan alat. 


\section{HASIL DAN PEMBAHASAN}

\section{Tegangan tanpa Beban}

Pengukuran tegangan tanpa beban dilakukan pada awal pengujian dan setiap 1 jam setelah diberikan beban LED. Hasil pengukuran tegangan alat selama 3 hari pengujian untuk setiap elektrode dapat dilihat pada Gambar 2. Berdasarkan Gambar 2, dapat diketahui bahwa elektrode $\mathrm{Cu}-\mathrm{ZnMg}$ menghasilkan tegangan paling tinggi dibandingkan dengan elektrode $\mathrm{Cu}-\mathrm{Zn}$ dan $\mathrm{Cu}-\mathrm{ZnAl}$ pada saat alat tidak diberikan beban. Nilai tegangan tanpa beban untuk elektrode $\mathrm{Cu}-\mathrm{Zn}, \mathrm{Cu}-$ $\mathrm{ZnAl}$ dan $\mathrm{Cu}-\mathrm{ZnMg}$ pada awal waktu pengujian di hari pertama masing-masing sebesar $10,19 \mathrm{~V}, 12,89 \mathrm{~V}$, dan 25,57 V. Elektrode $\mathrm{Cu}-\mathrm{ZnMg}$ memiliki nilai keluaran daya yang fluktuatif. Begitu pula pada elektrode $\mathrm{Cu}-\mathrm{Zn}$ dan $\mathrm{CuZnAl}$ akan tetapi hanya di waktu-waktu tertentu. Fluktuasi nilai keluaran daya tersebut dapat disebabkan oleh jarak antar elektrode yang tidak tetap, karena jarak antar elektrode juga mempengaruhi keluaran tegangan dan arus dari sel elektrokimia [7]. Penambahan bahan logam yang memiliki nilai potensial yang lebih jauh sebagai anode korban menghasilkan nilai tegangan yang lebih tinggi. Nilai tegangan yang diberikan oleh elektrode dengan anode korban magnesium

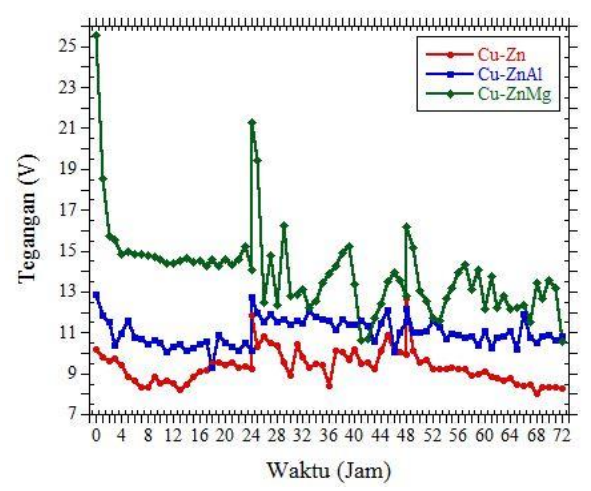

Gambar 2. Grafik pengukuran tegangan tanpa beban selama 72 jam. memiliki nilai yang lebih tinggi dibandingkan elektrode dengan anode korban aluminium. Hal tersebut dapat diakibatkan oleh beda potensial dari logam zink ke logam magnesium lebih jauh dibandingkan beda potensial dari logam zink ke logam aluminium. Berdasarkan nilai potensial elektrode standar, dapat diketahui bahwa logam aluminium memiliki nilai potensial sebesar $-1,66 \mathrm{~V}$ dan logam magnesium memiliki nilai potensial sebesar -2,37 V. Beda potensial dari elektrode $\mathrm{Cu}-\mathrm{Zn}$ sebesar $1,1 \mathrm{~V}$, sedangkan elektrode $\mathrm{Cu}-\mathrm{ZnAl}$ dan $\mathrm{Cu}-\mathrm{ZnMg}$ memiliki beda potensial masing-masing sebesar 2,76 dan $3,47 \mathrm{~V}$. Adanya perbedaan potensial yang jauh antara elektrode $\mathrm{Cu}-\mathrm{Zn}$ tanpa anode korban dan elektrode $\mathrm{Cu}-\mathrm{Zn}$ dengan anode korban, sehingga menghasilkan nilai tegangan listrik yang lebih besar [12]. Hal ini dapat disimpulkan bahwa penambahan logam sebagai anode korban berpengaruh pada nilai tegangan tanpa beban. Selain itu, penambahan luas elektrode yang digunakan juga sangat berpengaruh terhadap nilai tegangan tanpa beban. Semakin luas permukaan elektrode, maka nilai tegangan semakin tinggi [7]. Dengan menghasilkan nilai tegangan yang lebih tinggi, logam magnesium dapat juga digunakan sebagai pasangan anode, seperti penelitian yang telah dilakukan oleh $[15,16]$.

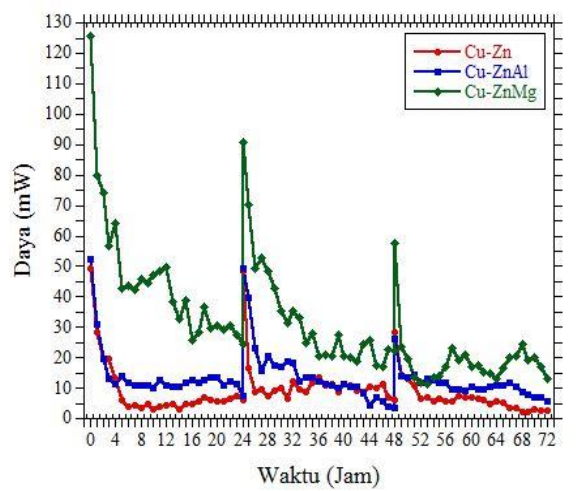

Gambar 3. Grafik hubungan daya terhadap waktu pengujian. 


\section{Daya}

Nilai daya listrik dihitung berdasarkan pengukuran tegagan dan arus saat diberi beban. Daya listrik yang dihasilkan oleh alat dari 3 macam perlakuan elektrode disajikan pada Gambar 3. Berdasarkan Gambar 3, dapat diketahui bahwa elektrode dengan anode korban menghasilkan keluaran daya yang lebih tinggi selama 72 jam pengujian. Penambahan logam lain pada elektrode zink sebagai anode korban menunjukkan bahwa adanya penambahan luas permukaan elektrode. Semakin luas permukaan elektrode yang bereaksi di dalam elektrolit, maka energi listrik yang dihasilkan akan semakin besar [7].

Elektrode $\mathrm{Cu}-\mathrm{ZnMg}$ menghasilkan nilai daya yang lebih tinggi dibandingkan elektrode $\mathrm{Cu}-\mathrm{ZnAl}$. Menurut [12], adanya anode korban menghasilkan potensial sel yang lebih besar sehingga memungkinkan terjadinya reaksi redoks yang lebih besar. Keluaran daya maksimum elektrode $\mathrm{Cu}$ $\mathrm{ZnMg}$ selama 24 jam pertama sebesar $125,71 \mathrm{~mW}$, sedangkan elektrode $\mathrm{Cu}-\mathrm{Zn}$ dan $\mathrm{Cu}-\mathrm{ZnAl}$ masing-masing memiliki keluaran daya maksimum sebesar 49,49 $\mathrm{mW}$ dan 52,48 $\mathrm{mW}$. Setelah 24 jam pengujian, keluaran daya pada awal pengujian mengalami kenaikan dengan nilai daya elektrode $\mathrm{Cu}-\mathrm{Zn}, \mathrm{Cu}-\mathrm{ZnAl}$, dan $\mathrm{Cu}$ $\mathrm{ZnMg}$ masing-masing sebesar $48,36 \mathrm{~mW}$, 49,37 mW, dan 90,89 $\mathrm{mW}$.

Hal tersebut disebabkan oleh penggantian elektrolit air laut dan pembersihan elektrode. Penggantian elektrolit berpengaruh terhadap kadar garam yang terdapat pada sel elektrolit lebih banyak [11]. Untuk pengujian selama 24 jam ketiga, daya maksimum yang dihasilkan dari setiap elektrode sebesar 28,52 mW untuk elektrode $\mathrm{Cu}-\mathrm{Zn}, 26,20$ $\mathrm{mW}$ untuk elektrode $\mathrm{Cu}-\mathrm{ZnAl}$, dan 57,56 $\mathrm{mW}$ untuk elektrode $\mathrm{Cu}-\mathrm{ZnMg}$. Nilai keluaran daya listrik juga berpengaruh terhadap intensitas cahaya dari beban LED yang terhubung. Intensitas cahaya maksimum yang dihasilkan oleh alat pada hari pertama sebesar 213 lux untuk elektrode $\mathrm{Cu}-\mathrm{Zn}, 271$ lux untuk elektrode $\mathrm{Cu}-\mathrm{ZnAl}$, dan 500 lux untuk elektrode $\mathrm{Cu}-$ ZnMg. Pada hari kedua pengujian, diperoleh nilai intensitas cahaya maksimum elektrode $\mathrm{Cu}-\mathrm{Zn}, \mathrm{Cu}-\mathrm{ZnAl}$, dan $\mathrm{Cu}-\mathrm{ZnMg}$ masing-masing sebesar 84 lux, 251 lux, dan 300 lux.

Untuk pengujian pada hari ketiga, nilai intensitas cahaya maksimum yang dihasilkan dari elektrode $\mathrm{Cu}-\mathrm{Zn}$ sebesar 53 lux, sedangkan elektrode $\mathrm{Cu}-\mathrm{ZnAl}$ dan $\mathrm{Cu}-$ $\mathrm{ZnMg}$ menghasilkan nilai sebesar 40 lux dan 90 lux, berturut-turut. Berdasarkan nilai daya dan intensitas cahaya yang dihasilkan, dapat diketahui bahwa semakin besar nilai daya listrik yang dihasilkan, maka nilai intensitas cahaya yang terukur akan semakin besar.

\section{Laju Korosi}

Berdasarkan pengujian alat selama 3 hari diperoleh laju korosi setiap perlakuan seperti pada Tabel 1. Data yang diukur berupa perubahan massa elektrode selama pengujian berlangsung. Laju korosi dihitung menggunakan Persamaan 1, dengan densitas logam zink sebesar 7,13 $\mathrm{gr} / \mathrm{cm}^{3}$ dan luas permukaan elektrode zink yang terendam sebesar $56 \mathrm{~cm}^{2}$. Penelitian yang telah dilakukan, menghasilkan nilai perubahan massa elektrode yang berbeda. Massa elektrode yang berubah diakibatkan oleh reaksi kimia yang terjadi antara elektrode dan elektrolit.

Berdasarkan Tabel 1, dapat diketahui bahwa logam zink dengan penambahan anode korban magnesium ( $\mathrm{Zn}-\mathrm{Mg}$ ) menghasilkan nilai laju korosi yang paling rendah. Logam zink dengan anode korban magnesium menghasilkan nilai laju korosi yang lebih rendah dibandingkan logam zink dengan anode korban aluminium. 
Tabel 1. Laju korosi elektrode zink.

\begin{tabular}{clcc}
\hline No & Elektrode & $\begin{array}{c}\text { Kehilangan } \\
\text { massa (gr) }\end{array}$ & $\begin{array}{c}\text { Laju korosi } \\
\text { (mm/tahun) }\end{array}$ \\
\hline 1 & $\mathrm{Zn}$ & 0,0340 & 0,1036 \\
2 & $\mathrm{Zn}-\mathrm{Al}$ & 0,0304 & 0,0926 \\
3 & $\mathrm{Zn}-\mathrm{Mg}$ & 0,0260 & 0,0790 \\
\hline
\end{tabular}

Hal tersebut dapat disebabkan oleh potensial standar dari magnesium yang lebih kecil dari aluminium, sehingga menyebabkan logam magnesium terserang korosi lebih cepat. Kinerja logam magnesium sebagai anode korban lebih tinggi dibandingkan logam aluminium dengan nilai laju korosi sebesar 0,0790 $\mathrm{mm} /$ tahun. Laju korosi elektrode yang lebih rendah juga berpengaruh terhadap keluaran energi listrik yang lebih tinggi $[10,11]$.

\section{KESIMPULAN}

Penambahan logam lain sebagai anode korban berpengaruh terhadap keluaran elektrik dan laju korosi. Elektrode $\mathrm{Cu}$ $\mathrm{ZnMg}$ menghasilkan daya maksimum paling tinggi dan laju korosi elektrode zink paling rendah. Elektrode dengan penambahan anode korban yang lebih jauh jarak potensial standarnya dapat menghasilkan keluaran elektrik yang lebih tinggi dan lama serta laju korosi yang lebih rendah.

\section{UCAPAN TERIMAKASIH}

Penulis mengucapkan terima kasih kepada Kepala Laboratorium Elektronika Dasar dan Instrumentasi Jurusan Fisika FMIPA Universitas Lampung yang telah membantu dalam penyelesaian penelitian ini.

\section{DAFTAR PUSTAKA}

[1] I. Kholiq, "Pemanfaatan Energi Alternatif sebagai Energi Terbarukan untuk Mendukung Subtitusi BBM," J. IPTEK, vol. 19 , no. 2, pp. 75-91, 2015.
[2] P. R. Roberge, Corrosion Engineering Principles and Practise, vol. 33, no. 1. USA: The McGraw Hill Companies, 2008.

[3] S. Fariya and S. Rejeki, "Seacell ( Sea Water Electrochemical Cell ) Pemanfaatan Elektrolit Air Laut Menjadi Cadangan Sumber Energi Listrik Sebagai Penerangan Pada Sampan," J. Sains dan Teknol., vol. 10, no. 1, pp. 44-58, 2015.

[4] Riyanto, Elektrokimia dan Aplikasinya. Yogyakarta: Graha Ilmu, 2013.

[5] D. Yulianti, Analisis Kelistrikan Sel Volta Memanfaatkan Logam Bekas. Bandar Lampung: Universitas Lampung, 2016.

[6] E. Hudaya, Analisis Karakteristik Elektrik Air Laut sebagai Sumber Energi Listrik Terbarukan. Bandar Lampung: Universitas Lampung, 2016.

[7] A. Susanto, M. S. Baskoro, S. H. Wisudo, M. Riyanto, and F. Purwangka, "Performance of $\mathrm{Zn}-\mathrm{Cu}$ and $\mathrm{Al}-\mathrm{Cu}$ electrodes in seawater battery at different distance and surface area," Int. J. Renew. Energy Res., vol. 7, no. 1, 2017.

[8] A. Susanto, M. S. Baskoro, S. H. Wisudo, M. Riyanto, and F. Purwangka, "Seawater battery with $\mathrm{Al}-\mathrm{Cu}, \mathrm{Zn}-\mathrm{Cu}$, Gal-Cu electrodes for fishing lamp," Int. J. Renew. Energy Res., vol. 7, no. 4, 2017.

[9] A. Maulan, D. A. Randi, D. G. Winandar, and A. N. Maghfiroh, "Pemanfaatan Air Laut sebagai Media Penyuplai Kebutuhan Listrik Kapal," Simp. Nas. Teknol. Terap., 
vol. 5, pp. 1-7, 2017.

[10] R. K. Arwaditha, Desain dan Realisasi Akumulator Elektrolit Air Laut dengan Penambahan Sodium Bicarbonate (NaHCO3) sebagai Sumber Energi Alternatif. Bandar Lampung: Universitas Lampung, 2017.

[11] S. S. Pangestu, Analisis Laju Korosi pada Sistem Energi Listrik Alternatif Berbasis Elektrolit Air Laut. Bandar Lampung: Universitas Lampung, 2017.

[12] F. Rahmawati, Elektrokimia: Transformasi Energi Kimia-Listrik. Yogyakarta: Graha Ilmu, 2013.

[13] I. Utami, "Proteksi Katodik dengan Anoda Korban sebagai Pengendali Laju Korosi Baja dalam Lingkungan Aqueous," Tek. Kim., vol. 3, no. 2, pp. 240-245, 2009.
[14] E. J. Sasono, Sulaiman, S. Darmanto, and E. Supriyo, "Analisa Perbandingan Laju Korosi Lambung Kapal dengan Aplikasi Paduan Alumunium," TEKNIK, vol. 9, no. 1, pp. 28-34, 2014.

[15] Supriyono, L. P. M. I. Wulaningfitri, J. C. Pradana, I. Feliani, and A. N. Putri, "Karakteristik Performa Discharge Anoda Magnesium Teranodisasi yang Teraktivasi oleh Air Laut," Rekayasa Bahan Alam dan Energi Berkelanjutan, vol. 1, no. 2, pp. 56-62, 2017.

[16] D. N. B. Utama, I. R. Kusuma, and S. Sarwito, "Perencanaan Energi Listrik Alternatif Tenaga Air Laut dengan Menggunakan Magnesium sebagai Anoda untuk Penerangan Alternatif pada Kapal Nelayan," Tek. ITS, vol. 5, no. 2, pp. 406-412, 2016 
Kamalia dkk.: Analisis Laju Korosi Elektrode Bahan Cu-Zn dengan Metode Sacrificial Anode Pada Sistem Energi Listrik Alternatif Berbasis Air Laut 